\title{
IMPLEMENTATION OF THE INDONESIAN CULTURE DIPLOMACY TOWARD AUSTRALIA THROUGH INDOFEST PERIOD 2012-2016 (CASE STUDY: ADELAIDE AND CANBERRA)
}

\author{
Ulyantraja Kelamor \\ International Relations, Universitas Kristen Indonesia, Jakarta \\ ulyantraja@gmail.com
}

\begin{abstract}
This journal discusses IndoFest activities which are conducted by Indonesia to Australia in 2012 to 2016 in Adelaide and Canberra. IndoFest was born in 2008, aims to introduce Indonesian culture in the international world. With the presence of IndoFest, it is also seen that cultural diplomacy continues to be done by Indonesia not only for improving good relations in both countries but also to introduce Indonesian art, culture, and exceptional food for more to the Australian people, in order to visit Indonesia. This journal also discusses Indonesia's cultural diplomacy towards Australia through IndoFest, as well as various activities in IndoFest to attract Australian tourists to come to Indonesia. As the research method, the qualitative method is used in this journal by library study, which is collecting the data from the literature related to the issue discussed. The results of the study stated that Indonesia successfully carried out its cultural diplomacy to Australia through IndoFest.
\end{abstract}

Keywords: Cultural Diplomacy, IndoFest, Indonesia, Australia, Culture

DOI: 10.33541/sp.v19i1.1642

Sociae Polites : Majalah IImiah Sosial Politik

Faculty of Social and Political Science, Universitas Kristen Indonesia

ISSN 1410-3745 print/ ISSN 2620-4975 online

Volume 19, Number 1 (January - June 2018)

Pages 33-52 


\section{Introduction}

The existence of a country on the international stage is now pressing for it a bond of cooperative relations that support each other for the achievement of interdependent needs each country involved. Fundamental knowledge in relationships an international state is unable to meet all forms of needs of its citizens if there is no cooperation interaction outside the internal boundaries of a nation. Nature and the existence of each country differ from one another in terms of ownership, natural resources, technology, labor resources, military forces, and the like. Countries need to work together to inform national interests based on the state-also, the same cultural fieldwork. The purpose of this collaboration is to obtain benefits or benefits from other countries or institutions.

To introduce Indonesia to the world, Indonesia does work the same as other countries. One of them is with Australia. Generally, Indonesia-Australia relations in all fields can describe as getting more reliable and more mature, with the results of cooperation between the two countries that have made a positive contribution to the progress of Indonesia-Australia bilateral relations. Under the administration of President Susilo Bambang Yudhoyono (SBY) where the view of Indonesia's foreign policy at that time was "a thousand friends zero enemies, "Indonesia Festival (IndoFest) was born in 2008. With the birth of IndoFest to introduce the culture and uniqueness of Indonesia to parties outside Australia especially seems to strengthen the statement of different political views Indonesia at that time.

Therefore, non-political factors (an example is cultural recognition activities through IndoFest) who has the binding power to anticipate political tensions and also restore Indonesian confidence (Prabaningtyas 2013,2). Cooperation bilateral in the socio-cultural field took place without significant obstacles in the middle of the dynamics of the ups and downs of RIAustralia political relations throughout 2013 (Media 2014, 39). To continue to maximize the friendship between the two countries, Indonesia has made its various approaches, one of them through cultural diplomacy. Cultural diplomacy is to believe as one of the means to maintain good relations with one of the countries of Indonesia's closest neighbor. Through cultural diplomacy, too many activities or events formed by Indonesia, one of which is through the implementation of IndoFest, which includes music or songs, culinary, and Indonesian dances.

Talk about culture, not only artistic expression but also culinary (Media 2014,36). Indonesian variety of culinary with full confidence introduced its exceptional food in Australia. As reviewed on the IndoFest Website which states that "The local Indonesian community has been bringing the cuisine and culture of one of Australia's closest and most important neighbor to Adelaide since 2008" (IndoFest.com.au,2016) shows that Indonesia is indeed severe about promoting culture Indonesia. It can be seen from the existence of the Indonesian community in Australia, bringing Indonesian cuisine and culture in Adelaide since 2008. RI Ambassador to Australia, Nadjib Riphat Kesoema in Adelaide, stated that IndoFest is the largest IndoFest in Australia. The biggest is also in the southern hemisphere of the earth. The aim is to unite the culture of the two nations.

The event was a form of joint work between the Ministry of Tourism together with the Indonesian Embassy (KBRI) in Australia and The Australian-Indonesian Association. Not only in Adelaide, IndoFest which is held routinely every year by the Indonesian Embassy in Canberra has also succeeded in becoming a cultural icon in the Australian capital, Canberra. This cultural promotion event increasingly crowded by residents around. Indonesia Festival or Yang, commonly called IndoFest, is also one of the ways to greet South Australians with Wonderful Indonesia culture and art. If we look at the practice of Government, we find that typically treat public diplomacy as covering culture, media, education, tourism, and related activities, plus outreach to foreign and home publics (Rana 2011, 79). 
Through the activities held by the Government of Indonesia, namely IndoFest, Ambassador RI for Australia, Nadjib Riphat Kesoema, said that this aimed at introducing more closely the various arts, cultures, and special foods of Indonesia to the people of Australia and finally wanting to visit Indonesia in person. The activity also aimed at uniting the peoples of the two nations. Indonesian and Australian people differ in values and culture but can become friends because the two countries increasingly understand each other through cultural and culinary events such as IndoFest. The author takes IndoFest held in Australia, specifically in this case in Adelaide and the Indonesian Embassy in Canberra as writing material to see how the role of Indonesian Cultural Diplomacy. This title is interesting because the writer chose to take a cultural approach to see bilateral relations between the two countries when the method most frequently used by Indonesia is in the political framework-security.

The author chose the period of 2012-2016 to understand the dynamics of visitors who participated in IndoFest activities held in Adelaide and Canberra. The author takes the period of the past five years as a writing limit because of the results from IndoFest activities within the framework of Indonesia's Cultural Diplomacy towards Australia more visible in that period. Although IndoFestini's operations began in 2008 during the Susilo Bambang Yudhoyono leadership, it assumed that the results or impacts of the introduction of Indonesian sociocultural elements on Australia through the new IndoFest activities would be seen in the following years, in this case in 2012. The author also focuses on countries in Australia, namely Adelaide and Canberra, to see the uniqueness of the IndoFest held in Adelaide and the differences that stayed in the Indonesian Embassy in Canberra.

IndoFest is an event to strengthen the unity and unity of Indonesian people who live in Canberra and surrounding areas as well as to be more proud of the cultural and culinary richness that Indonesia has. Following the Government's commitment to seek promotion of Indonesia abroad, in this case, Australia. The responsibility of the Government of Indonesia can be said to be dangerous; this is evident from the existence of the biggest annual cultural promotion held by the Indonesian Embassy in Canberra to introduce more closely the variety of arts, culture, and food typical of Indonesia to the people of Australia. It hoped that through IndoFest, Australians would become increasingly familiar with Indonesian art and culture, increasingly liking Indonesian food, and of course, the impact will be on growing desire to travel directly to Indonesia.

The author posed the research question: How is the Implementation of Indonesian Cultural Diplomacy towards Australia Through IndoFest Activities 2012-2016? This study aims to determine the extent of Indonesia's cultural diplomacy towards Australia carried out through the implementation of IndoFest activities in Australia. The results to be achieved in this study are: Examining the Implementation of Indonesian Cultural Diplomacy towards Australia Through Activities IndoFest Period 2012-2016.

\section{Literature Review}

In general, Indonesia-Australia relations in all fields can describe as getting more reliable and more mature. With the results of cooperation between the two countries that have provided positive contribution not only to the progress of Indonesia-Australia bilateral relations. Also, the development of participation in the region. Indonesia-Australia cooperation takes place dynamic throughout 2013; This was because of the emergence of several challenges that impacted the ups and downs of collaboration between the two countries.

Indonesia-Australia relations throughout 2013 marked by two visits by the Australian Prime Minister Indonesia; and three bilateral meetings at the Minister of Foreign Affairs level, including one meeting with the Ministers of Defense of the two countries (Media 2014, 36). Through diplomacy journals, as the first literature review by the author, dynamically Indonesia- 
Australia relations can be added not only in terms of the moment of tension but also how cultural cooperation between the two sides continues to carry out well. In this case, alliances carried out through diplomacy culture.

Commonly recognized that relations are not always intimate, and throughout the history of relations between the two countries (Indonesia-Australia), which are direct neighbors, there are still ups and downs. It is a problem between Indonesia and Australia as neighbors, which cannot be separated, namely how to manage relations in such a way that shocks can be minimized or even become productive relations and mutual benefit. Relationships that described as a roller-coaster, that is, go up slowly but go down very sharply, are already a part of the history of relations between the two countries. In addition to socio-cultural differences and levels of development, the two countries have different views and interests both within the framework bilateral and regional and international relations (Bhakti 2008, 33).

Through the literature review above, it looks that even though Indonesia-Australia has established excellent and long-standing cooperation, yet it has become the closest friend country. Still, the relations between the two countries are not always harmonious. It was said earlier in the Journal that Indonesia-Australia relations we're dynamic, there were ups and downs, which means that even though the two countries could not be separated, IndonesiaAustralia relations are also inseparable from the problems that occur. Something that can add from the journal through the thesis of the writer is that there are factors that are still being carried out by the two countries in the context of increasing relations or cooperation towards a more serious one.

Although problems often encountered in ties between the two countries, there are areas of collaboration that are not affected by conflicts that could have surfaced in the fabric of Indonesia-Australia relations. The field of cooperation that remains and continues to be developed more creatively by Indonesia, namely through cultural activities to strengthen good relations between the two countries. Thesis writing looks at how Indonesia plays its cultural diplomacy through IndoFest activities. The existence of IndoFest shows that the two countries are trying to continue to manage excellent relations in such a way in sharing fields, one of which is through the artistic side to Producing relationships and creating an atmosphere of mutual benefit.

Cultural diplomacy carried out so that Australians know Indonesia with their culture through a variety of activities carried out in IndoFest, namely the introduction of music, Indonesian songs. The existence of Indonesian culinary and dances shows that IndoFest is also a place to strengthen the unity and integrity of Indonesian people living in Australia so that Indonesian people are more proud of their cultural and culinary riches. Moreover, Indonesia introduced more closely the various arts, Indonesian culture, and food to the Australian people to implement cultural diplomacy optimally. In the end, this writing will see how the success of the cultural diplomacy that Indonesia has achieved for the community Australia through IndoFest activities, especially in the 2012-2016 period.

\section{Research Method}

In this study, there are several things to be considered, which are: this study wants to show that in the implementation of cultural diplomacy. In the context of promoting Indonesian culture specifically through IndoFest activities held in Adelaide and Canberra, Australia. Not only the role of the Government, the role of the Ambassador, Deputy Ambassador, or only Diplomats who are representatives of Indonesia but also the support of the Indonesian people in Australia is needed so that this IndoFest activity can run successfully. This research also expected to find out what Indonesia is doing in implementing IndoFest activities in Adelaide 
and Canberra in the context of promoting Indonesian culture. It will be explained descriptively by the writer; then, the writer will conduct an analysis of the issues raised.

The author uses a Qualitative Research approach. Qualitative methods are appropriate for studying attitudes or behaviors in natural environments rather than in somewhat artificial situations, such as in surveys or experiments (Mulyana and Solatun 2013, 13). As a nature of data, the term qualitative not intended as opposed to quantitative terms. A study may use a scientific / object / deductive paradigm with experimental methods and use sophisticated statistical tests. Still, part of the data analysis is carried out qualitatively by interpreting the data. In this sense, there is no purely quantitative research. An author may also adopt a structural-functional theory that tends to have a scientific paradigm, but it may be possible to collect qualitative data. Quantitative data can combine with qualitative data as it based on the same standard (e.g., structural-functional paradigm), even though one of the categories of data, for example, quantitative data, is usually more dominant than qualitative data, or vice versa.

Qualitative research is descriptive research in which, as a type of research that seeks to describe how an event occurs, provides a picture of reality in the object under study as it is. The purpose of this descriptive method is to make a systematic, factual, and accurate description, description, or painting of the facts, properties, and relationships between the phenomena investigated. In this research, the descriptive study in question is a descriptive analysis. This type of research is descriptive analysis writing that seeks to describe the phenomena that have and are happening and to explain the sequence of events or relationships between facts. The qualitative research approach was to choose because this study aims to describe the steps and strategies undertaken by the Indonesian Government in the context of implementing Cultural Diplomacy, which aims to promote Indonesia in Australia.

According to Miles and Huberman, qualitative data is the source of a full and firmly based on description and contains an explanation of the processes that occur in the local sphere. With qualitative data, we can follow and understand the chronological flow of events, assess causality within the minds of local people, and obtain many and useful explanations. Also, qualitative data is more inclined to guide us to achieve unexpected discoveries and to form new theoretical frameworks (Silalahi 2009, 284-285). In this study, the author conducted a literature review as not only a guideline in the context of thought but also the theoretical foundation more utilized as a guide. So the focus of the research was appropriate in the field. The foundation of this theory intended to provide a general description and explanation of the background of research also material in the discussion of research results.

The data collection techniques that the author uses in this research are library research, which is by collecting data from the literature relating to the problem to be discussed and then analyzing it. Data sources for collecting qualitative data are not only humans who can express opinions using words (oral and written) but can also be from written sources that interpreted (Nawawi and Hadari 2006, 51). Related to the literature mentioned above can be in the form of books, documents, journals, magazines, newspapers, and internet sites or reports relating to the problem to be examined by the author. This library research is conduct to find research data or information through reading scientific journals, reference books, and publication materials available in the library (Ruslan 2003, 31).

Secondary data is data obtained from other parties or outside the library research model. Secondary data can be in the form of documentation data or report data that has been available from internet sites (Nasir 1999, 63). Cultural Diplomacy conducted by Indonesia in this matter by the Government of Indonesia towards Australia, as well as the forms and strategies undertaken by the Government of Indonesia in carrying out Indonesian cultural diplomacy towards Australia, this research will using primary sources and secondary sources. The primary source for this research is through in-depth interviews. While the secondary source for this research is through various collections consisting of books, journals, reports, magazines, 
papers, and analysis of media content such as print or electronic media such as the internet. The author will also use the source of documents for this research. In general, the informants who became the primary source of research data divided into two, namely: First, the source of data to explain the Cultural Diplomacy itself in general and the Cultural Diplomacy carried out by the Government correctly. Second, a source of data describing the forms and activities carried out by the Government of Indonesia towards Australia in the dual Indonesian promotion.

This research is descriptive analysis to be able to provide an overview of the situations and conditions that occur as well as analyzing the circumstances and conditions that arise. Data analysis techniques in this study by systematically compiling data obtained. Both data from the literature. Also, other sources will be analyzed again to capture the essence of the problem under investigation. The process of data analysis starts with reducing data. The data collected needs to be recorded carefully and in detail. Reducing data by summarizing, choosing the main points, focusing on the essential things, looking for themes, and patterns of data that has collected. Overall data obtained categorized according to the problem and research purposes. After reducing the data, the data presentation starts in the form of a brief description and the relationship between categories. With the performance of the data, it will be easy to understand and plan the next research process. Based on data that has been collected and then analyzed so that it can lead to a complete conclusion, the conclusion can be an answer to the formulation of the problem. It can also be a new finding that has never been there (Prof. Sugiyono 2009, 247-252). Based on the approach used in this study, the data collection methods used are in the form of words, pictures, and not numbers. 


\section{Results and Discussions}

Figure 1. Ondel-Ondel Betawi in the event Indofest di Adelaide

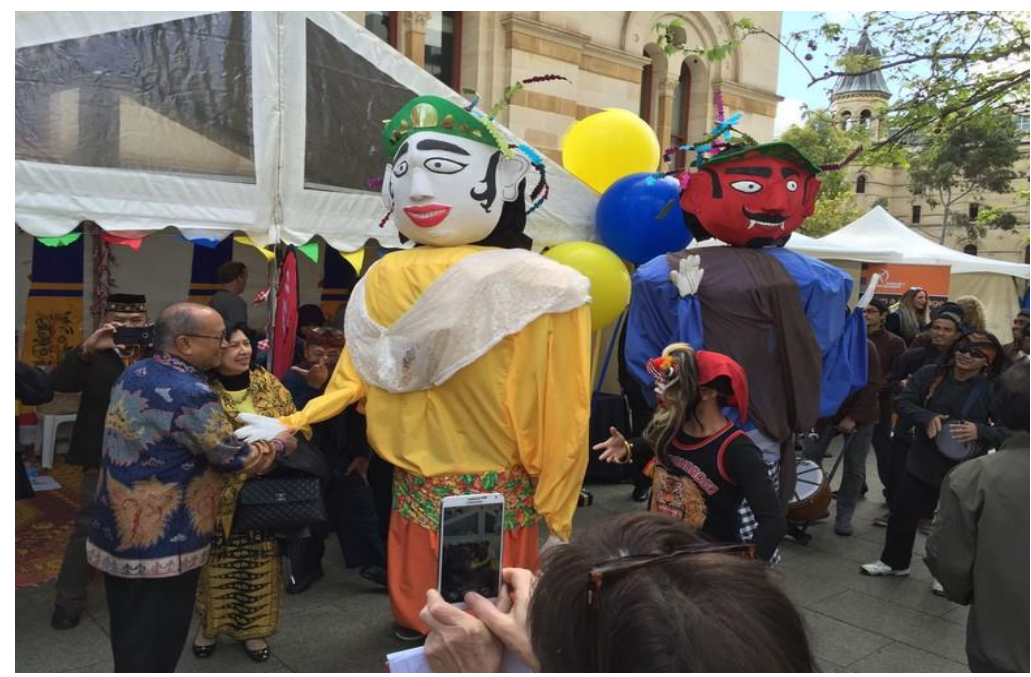

Source:

https://news.detik.com/berita/d-3307236/ondel-ondel-betawi

IndoFest is a collaborative effort of the South Australian Indonesian community of South Australia. It hosted by the volunteer and not-for-profit Australian-Indonesian Association (AIA) of South Australia (IndoFest.com, 2017). IndoFest also parts public diplomacy in the form of art and culture. IndoFest held in Adelaide and Canberra has the same goal as mentioned above but has differences. Naming activities to promote Indonesian culture in Canberra, more familiarly called the Indonesian Festival activities.

IndoFest in Adelaide supported by various governments in Australia and Indonesia. Such as the state of South Australia, the Adelaide city council. For several years, This IndoFest supported by the Federal Government of Australia. Also, funding came from the Ministry of Culture and Tourism in Jakarta. The format of IndoFest events in Adelaide is very varied and takes place over a certain period, which can spread in various areas and months. Towards the end of the peak, the event held on one (1) or two (2) days on weekends-IndoFest in Adelaide dedicated to a game that can be attended by all family members.

The activity involved many parties from the Australian Government, schools, and the Australian community. Another difference from IndoFest held in Adelaide and Yang held in Canberra is whereIndoFest Adelaide combines paid, and voluntary professionals, and every preparation is also done very professionally (Indonesian Embassy in Canberra, 2017).

Through IndoFest, the Indonesian Embassy in Canberra promotes Indonesian culture, cuisine, and tourism destinations to the Australian public. IndoFest is an integral part of the Government of Indonesia's policy to support the arts, culture, cuisine, and tourism of Indonesia in Australia. IndoFest's implementation policy has not changed since the days of President Susilo Bambang Yudhoyono until now (Indonesian Embassy in Canberra, March 14, 2017).

Since 2008, IndoFest has been bringing the colors, flavors, and sounds of Indonesia to South Australia. This annual event aims to strengthen ties between Australia and our closest neighbor. IndoFest's main objectives are to Express Indonesian art and culture; Project the progressive development of contemporary Indonesia. Also, Encourage the study of Indonesian language and educational links with Indonesia, Stimulate and recognize people-to-people (pto-p) connections that give strength to the Indonesia-South Australia relationship. Foster youth ties between Indonesia and South Australia in the context of mutual community relations and 
future nation-building; Help create and provide opportunities for trade, commercial business, and tourism between Indonesia and South Australia (Adelaide.edu.au, 2014).

In the IndoFest activities held at the Indonesian Embassy in Canberra, there were four (4) promotional activities that presented. First, culinary promotions from various regions in Indonesia. Second, a cultural development that starts from the morning to the afternoon. Third, the existence of the Balinese gamelan and Javanese gamelan introduced in the Balai Kartini room at the Indonesian Embassy in Canberra. Fourth, there is an Indonesian Tourism exhibition - the exhibition held in the Indonesian Embassy in Canberra. Also, the transformed in such a way as to attract the interest of IndoFest visitors (Op.Cit., Indonesian Embassy in Canberra). It was done as a place to introduce the socio-cultural elements of Indonesia towards Australia, which brought color to the bilateral relationship between Indonesia and Australia. Another uniqueness given by the Indonesian Embassy in Canberra is the opportunity for visitors to play gamelan music as a tour of knowledge, including for students or students who come to visit the Indonesian Embassy in Canberra.

Indonesia gives the new colors through IndoFest seen from the beginning of the event. Indonesian-style weaving is a thing new for Australians, such as gamelan, kulintang, angklung in the Indonesian Embassy in Canberra, which used as a training room between employees of the Indonesian Embassy in Canberra and Australians. IndoFest, which held on April 13, 2008, involved Australia Indonesian Association (AIA), Indonesian people living in Australia, as well as art galleries and higher education institutions in Rymill Park, Adelaide, which also enlivened IF activities. Since the first IndoFest event opened in 2008, the starting at 11.00 to ending around 16.00 Australian time, visitors entertained by the Balinese dance "Panyembrana," a parade of traditional clothing, and chanting of songs Indonesia donated by local students. After that, there was also a Sundanese musical art performance by Dodi Darmadi and friends, Saman dance, Angklung, Gambyong Pangkur dance, Quartet Line Karawitan band that combined elements of Indonesian and Western music, and Pencak Silat. Several stages built for dangdut music performances, Balinese Kebyar Duduk dance, and "Poco-Poco" dance (Kompas.com 2008). Several visitors too treated to a variety of traditional and contemporary Indonesian cultural arts performances.

The series of events during IndoFest consisted of a food and beverage bazaar, music and dance, an Indonesian cultural exhibition, and a kid's corner with a variety of traditional Indonesian children's toys that introduced to Australian children. The Government plays its role in cultural diplomacy, which realized in its relationship with Australia (Culture, Ministry of Education, Culture and Culture.go.id 2015). IndoFest's top event aimed at introducing Indonesia to city communities in the state of South Australia opened by Secretary III of the Indonesian Embassy in Canberra, Basriana Basrul, Ambassador of the Republic of Indonesia to Australia and Vanuatu, Nadjib Riphat Koesoema. The event takes place in the city park area, Rymill Park, open around 11:00 Adelaide time. Present were several local officials, including the Governor of South Australia, Kevin John Scarce, who was also the Chair of the state's Multi-Cultural and Ethnic Affairs Commission, Adelaide Mayor Michael Harbison, and the Indonesian Honorary Consul in Adelaide, Deane Edgecombe (Kompas.com 2008).

Various approaches have been taken by the Government of Indonesia to establish more harmonious relations and strengthen relations between the two countries in foreign cooperation with the closest neighbors, especially Australia. Keeping the peace and building trust in international is often about managing diversity, and ignored challenges in the past, and recognizes challenges for the future (Jora 2013, 48). It is what Indonesia believes through its cultural diplomacy towards Australia.

With the growing public knowledge in Australia, it's hoping that the enthusiasm and interest of young Australians, in particular, will grow, especially in learning the Indonesian language and culture. The ultimate goal is the growth of a better understanding at the level of 
Australian society about Indonesia, so expected to have a positive impact on improving relations between the two countries and the nation.

Cultural diplomacy as the promotion abroad of a state's Cultural achievements also defined broadly to include the advertisement of the accomplishments in science and technology as well as these arts, humanities, and social sciences. Cultural diplomacy attaches particular importance to promoting links between parallel institutions at home and abroad, for example, between domestic and foreign universities (Berridge and James 2001, 56).

Regarding cooperation between Indonesia and Australia, Indonesia works together with universities in Australia to help make IndoFest a success. One example is a group of students who also wear batik and sing several Indonesian songs, such as students at Flinders University, Adelaide at IndoFest 2016. It reflected in several art performances in IndoFest, such as Balinese Gamelan, Saman Dance, and Australians, including students, mostly play Manuk Dadali. Professor Nancy Comar, from Flinders University, said, that:

"We are (Flinders University) engaging, we're (Flinders University) increasingly encouraging our students to travel to Indonesia, also in a whole range of variables to encourage our students to experience Indonesia" (culture.kemdikbud 2015).

IndoFest is one of the tools used by the Government of Indonesia to introduce culture with all the uniqueness that Indonesia has, and to invite Australians to visit Indonesia with everything its advantages. Through IndoFest, many Australians have experienced incredible and educational experiences.

"Looking at being Indonesia and Australia stands today, these countries are in the process of developing and consolidating a mature, multi-layered, and multi-dimensional relationship with a growing level of understanding and appreciation. Indonesia and Australia have learned that they cannot sensibly ignore each other, and there is nothing to be gained and much to be lost by scoring points off each other. Australia is Indonesia's largest and closest neighbor, as well. On the other hand, Indonesia is Australia's largest and closest neighbor as well" (Soesastro 1995, 5).

Indonesia and Australia will continue to be neighbors, so the two countries are willing to work together in the field of culture that can strengthen relations between the two countries. Indonesia continues to try to introduce Indonesia further to the people of Australia about Indonesian culture (CultureKemdikbud.go.id, 2015). "Social relationships are a significant part of people's lives; however, their importance varies based on different cultural contexts and norms. It should note that "togetherness" is an essential value in most Asian countries, including Indonesia. According to Novera (2004), Asian people integrated into strong, cohesive in-groups; therefore, group concerns are usually more important to them than individual interests" (Molaei 2014, 52).

IndoFest activities held since 2008 by the then president of the Republic of Indonesia, SBY, were formed to introduce the culture and increase public insight Australia regarding the uniqueness and all the advantages (typical dances, music, or songs, special foods) owned by Indonesia. This activity was explicitly held in Adelaide and also in Canberra, namely, at the Indonesian Embassy in Canberra.

Held in Rymill Park, Adelaide, Indonesia presents several artistic performances, such as the Kuda Lumping dance performed by young Indonesians. Not only Indonesian youth, but there are also performances from Indonesian children. They dance with Javanese typical. Besides this, there is also Saman Dance. They are also presented by the return of Reog Singo Sarjono, performed by Indonesian people who invited admirers of IndoFest visitors in Adelaide. Not only dances but IndoFest2012 in Adelaide also featured the Angklung Adelindo show, as well as holding workshops around Angklung and Kulintang. Through the seminar, Australians who came to visit IndoFest taught how to play Angklung, and they too learn to 
play Angklung, also Koliintang, by bringing several Indonesian songs, such as the song Lenggang-Lenggang Kangkung while swaying.

Indonesian community and diplomatic representatives in Australia return introduce the arts and culture of the archipelago to the local community. Entitled IndoFest2013, the activity that took place in the City of Adelaide introduced various kinds of dance, traditional dishes, and paintings by Indonesian artists. The Indonesian Ambassador to Australia, Nadjib Riphat Kesoema, expressed his gratitude to the Governor of South Australia and the famous guests in attendance, the entire Committee and the Indonesian community in Adelaide who had made IndoFests the "The Best Indonesian Fair Abroad."

IndoFest is a promotional event for Indonesia in Adelaide, in collaboration with Australia-Indonesia Institute (AII) features arts and cultural performances, food bazaars, exhibitions of Indonesian products. The opening ceremony of IndoFest 2013 also attended by high officials of South Australia, including Governor Kevin Scarce, Minister for Employment Participation, Early Childhood and Child Care, Kate Ellis MP, who represented the Prime Minister of Australia. Also attending the Indonesian Honorary Consul in Adelaide, Deane Edgecombe, and Acting Ministry of Tourism and Creative Economy of the Republic of Indonesia.

Many activities carried out in IndoFest2013. Some of them are Indonesian children's songs, such as the Lizard on the Wall, also the song Saya Saya round. Uniquely, those who sing this song are Australians who then sing Indonesian children's songs in two languages. So don't just sing the song was in Indonesian, but also sang Indonesian children's songs in English. It's also to make it easier for Australian children better to understand the meaning of the Indonesian children's song. The existence of some of these songs makes the children who participate in IndoFests activities very cheerful, happy and laughing.

In addition to the activities above, Indonesia is also very distinctive with its dangdut music. In IndoFest in Adelaide, several dangdut songs were also performed, such as Terajana songs and Indonesian tambourine music that made the atmosphere. IndoFestsem's series of activities increasingly crowded because visitors who joined in the swaying and traditional Indonesian dances with skilled hands also taught to Australians in Adelaide who participated in IndoFest activities. To attend IndoFest 2013, Ambassador Nadjib also participated in an exhibition of paintings by Tok Basuki, an Indonesian painter who graduated from ISI Yogyakarta, who is currently living in Adelaide. Through the show "Cross-Section," Tok Basuki wanted to reveal that in the increasingly complex development of life in Yogyakarta, folk artists persisted and developed creativity to survive and, at the same time, maintain the cultural arts that had taken root in Yogyakarta society.

The painting exhibition event through IndoFest 2013 also featured Reog Ponorogo by the Singo Sarjono group in Adelaide. Ambassador Nadjib said he was very proud of the exhibition of Reog Ponorogo paintings and art, which was displayed by public Indonesia in Adelaide because the event was very appropriate in encouraging efforts to introduce the richness of Indonesian culture further.

Initiated with AIA, visitors can taste a variety of Indonesian culinary specialties at Rilley Park. IndoFest2014 features Saman Dance and Angklung musical instruments from West Java. Not only that, but there are also Betawi Ondelondel. Not to forget, the lumping horse dance equipped with a puppet figure, Hanoman. Even members of the AustraliaIndonesia Association, consisting of Australians, also performed Indonesian songs, such as the Halo-Halo Bandung song.

IndoFest is getting bigger and better from time to time, and also keeps getting support from the community in northern Australia that continues to attend. Australians are happy with the IndoFest event because this event is considered the most appropriate means to introduce Indonesian culture. IndoFest2014 fact is also unique entertainment for visitors. Also, not a few 
residents of the city of Adelaide who invited their children. Also, to submit the Indonesian culture.

The 2015 IndoFest has been held in the cultural center area in downtown Adelaide, including the Art Gallery, South Australian (SA) Museum, and Museum migration. IndoFest Adelaide looks offering activity from the Indonesian community in Adelaide for the Australian city in the state of South Australia (KJRI Sydney, May 30, 2017). Cultural art from Indonesia is the most critical cultural heart in South Australia. It looked when hundreds of visitors packed the IndoFest event at downtown Adelaide, which held on Monday, October 5, 2015. from morning to an evening with the Indonesian Ambassador to Australia, Nadjib Riphat Kesoema. Local officials were also present, including the Governor of South Australia Hieu Van Le AO, Minister of Affairs The culture of Zoe Bettison, who represented the Chief Minister (Premier), Jing Lee, described the opposition leader and Adelaide Mayor Martin Haese. For Nadjib Riphat Kesoema, IndoFestini is not only the largest in Australia but also the largest in the southern hemisphere. It is a cultural collaboration by the people of the two nations, which strengthens bilateral relations.

Various stands ranging from food stands, tourism, to workshops to make Balinese sculpture and lumping horses, were crowded with hundreds of visitors. Two indoor and outdoor stages seemed crowded. The visitors were enthusiastic while watching music, live bands, and arts from Aceh to Papua, such as the Langit Biru dance from West Java, the Jejer Banyuwangi dance, the Pangkur Sagu dance from Papua, the tambourine and angklung music. Flinders University students also performed very fluently in singing Abuse, Rasa SayangSayange, Nona Manis, Soleram, Maumere, and other songs. Ondelondel art from Betawi also enlivened the atmosphere of the festival.

Interestingly, the making of the giant Ondelondel was made two years ago with full funding from the City Government of Adelaide and designed by Australian designer (Ibid). Many children surround and play with giant Ondelondel, who walk around the location of the event. Cultural and culinary arenas become a crowd point. Adelaide community in droves come to enjoy Indonesian cuisines, such as satay, meatballs, rendang, and various other traditional Indonesian foods. The Ministry of Tourism of the Republic of Indonesia participated in supporting the success of IndoFest by sending cultural contingents from the country.

"IndoFest is the only festival in Australia that has been ongoing for eight times and has the full support of the Australian Government, particularly South Australia, and the Indonesian Embassy (Indonesian Embassy). The interest of Australians reaching 90 percent visited IndoFest, where this year, there are an estimated 10,000 visitors at IndoFest, "said Vincent Jemadu, Assistant Deputy of Asia Pacific Market Development at the Ministry of Tourism. IndoFest also raised the topic of discussion "Beyond Bali," which discusses tourist destinations other than Bali. Through cultural promotion, it expected that tourists from Australia to Indonesia in 2015 would reach 1.1 million visitors, more than last year, with less than 1 million homesteads.

The local people of Adelaide to Australian officials were amazed by the Indonesian arts and culture held on Sunday, September 25, 2016. The end remains the same, promoting tourism and all its advantages to Indonesia. According to Vincent Jemadu, Assistant Deputy for Asia Pacific Marketing Development at the Ministry of Tourism said that IndoFest is a festival that presents a portrait of mini Indonesia. From culinary to arts and culture. The residents of Adelaide crowded this activity. I was so attractive, not only thousands of Adelaide residents were present. Many Australian officials also took the time to watch the grand event.

Visitors look enthusiastic, viewing music, live bands, and art from Aceh to Papua. Start from angklung, and then there is Ega Robot Ethnic Percussion West Java. There are also Banyuwangi Jejer Dance, Lombok traditional warfare that presented through Peresean Dance, Bali Kecak Dance, Dance Papua Sago Pangkur to carnival costumes that were exhibited by 
Malang Amore Carnival, are all there. One resident of Victoria Park, Adelaide, Craig Cook, said that Indonesian art was very diverse and enjoyable. Through IndoFest, he became more acquainted that in Indonesia, it is not only Bali.

According to the Indonesian Ambassador to Australia, Nadjib, this event was indeed a great award presented by the Australian Government to Indonesia. All respect for our culture. A group of students also wore batik and sang several Indonesian songs, such as students at Flinders University, Adelaide, and this was extraordinary. At the same time, the comments of Australian officials were equally positive. Governor Hieu Van Le, for example. He mentioned that he is a loyal fan of IndoFest since it was first nine years ago. According to him, the packaging of this event was excellent, which raised culture. He acknowledged being a loyal fan of IndoFest's activities because, through this event, good relations between the people of Australia and Indonesia could establish a form of work together from people-to-people. The Australian Minister for Cultural Affairs, Zoe Bettison, also said his impression of IndoFest's activities that this is South Australia's commitment to supporting good relations with Indonesia. For him, the richness of Indonesian art and culture has added color to multiculturalism in Australia, especially Adelaide (Kompas.com 2008).

In IndoFest held in Canberra in 2012, the Indonesian Embassy presented several performances, including two (2) Indonesian teenage girls who sang the song "Someone Like You-Adelle." Besides that, there were also several traditional Indonesian dances. One of them is Betawi dance, which is a Betawi dance with several female dancers from Indonesia who use shawls as their typical dance and accompanied by some traditional musical instruments by many men who also come from Indonesia.

The Indonesian Embassy in Canberra held the IndoFest on Saturday, October 12, 2013, and began at 11:00 to 17:00 hours Canberra, Australia at the Indonesian Embassy, Darwin Avenue St, Yarralumla. In IndoFestCanberra in 2013, there were a variety of activities carried out, some of which were Indonesian Cuisine, Raffle Draw, performances, and others.

The 2014 IndoFest Canberra was held on October 18, 2014, and was open from morning to evening, from 11:00 to 17:00 (CommunitySwitch.com.au 2014). At IndoFest this time, the Republic of Indonesia Embassy (KBRI), in collaboration with several Indonesian communities residing in Canberra, held its IndoFest activities exactly at 8 Darwin Avenue, Yarralumla, ACT 2600. This event aims to promote and provide information for a better understanding of Indonesian culture and also to strengthen Indonesia-Australia relations. At IndoFest this time, there are more than twenty-five (25) stalls offered by the Indonesian Embassy that offer Indonesian cuisine and handicrafts worldwide. The community in Canberra also enjoyed the beautiful park at the Indonesian Embassy during IndoFest activities. Purwacaraka band as one of the well-known bands from Indonesia and the winner of the dangdut song competition helped make IndoFest events more lively.

IndoFest Canberra 2014 features a variety of music and dances, ranging from the traditional to modern forms of music and dance. The Indonesian Embassy in Canberra also gives exclusive prizes, including round-trip tickets from Sydney to Jakarta and Sydney to Bali, owned by Garuda Indonesia flight masks, and vouchers with a total value of $\$ 1000$ from sponsors involved in the IndoFest activities of the Indonesian Embassy in Canberra.

IndoFest 2015 held at the Indonesian Embassy in Canberra on October 10, 2015. This activity began at 11:00 local time until 16:00. The event began with remarks from the Indonesian Ambassador to Australia, Mr. Nadjib Riphat Koesoema. In IndoFest, Indonesia shows its various uniqueness, such as Saman Dance, Javanese Dance, Manuk Dadali Dance, Balinese Dance, Indonesian Archipelago Dance, where the dancers brought from Malang, Indonesia. Besides dances, the Indonesian Embassy in Canberra also presents fashion shows from various regions in Indonesia, such as fashion shows from East Nusa Tenggara (NTT). 
There are also offerings of Indonesian songs from students studying in Canberra. They sang several Indonesian songs, such as Soleram from Riau, and ManukDadali songs from West Java.

IndoFest, which has been held every year since 2008, is now a Cultural Icon in Canberra, the capital of Australia. It reflected in the increasing number of visitors who attend from year to year. At the eighth IndoFest, almost 5,000 people crowding the court of the Indonesian Embassy (Canberra) in Canberra. Hopefully, through this IndoFest, Australians will become increasingly familiar with Indonesian art and culture, increasingly liking Indonesian food, and of course, the impact is a growing desire to traveled directly to Indonesia. Besides, this cultural promotion activity is also to unite the peoples of the two nations. Indonesian and Australian communities differ in values and culture but can become friends because the two nations increasingly understand each other through cultural and culinary events like IndoFest.

IndoFest is an event to strengthen the unity and unity of Indonesian people living in Australia, as well as to be more proud of the cultural and culinary riches they possess. What's more, now thanks to very cultural diplomacy aggressive from the Indonesian Embassy in Canberra, more and more Australians love Indonesian culture. It reflected in several art performances in IndoFest, especially Balinese Gamelan, Saman Dance, and Manuk Dadali, which are mostly played by Australians, including students. They practice routine so that they can perform primed playing the rhythm of the Balinese gamelan, which is famous for being very smart and dynamic or dancing Saman, which has a high level of difficulty. Equally neat is the appearance of Indonesian and Australian students in Canberra when they exhibit the East Nusa Tenggara (NTT) woven clothing, which is a distinctive outfit in the province of NTT. The Malang Carnival Armor dance performed attractively by dancers brought directly from Malang became the main attraction for IndoFest visitors.

Australian students who join the Australia-Indonesia Youth Association (AIYA) also helped enliven IndoFest by volunteering to explain various woven fabrics and cultural objects on display. There are traditional dances, such as the Pendet Bali Dance, Manuk Dadali Dance, Tor-Tor Dance and Dangdut music, which has captivated the attention of the Australian public who for hours faithfully watched the show. IndoFest treated to variety culinary of the homeland, which very famous in Australia, ranging from chicken satay, satay, Gadogado, Pecel, warm, fried rice to snacks such as tofu contents and sausages as well as mixed ice and Dawet ice that was sold out by the visitors. One Australian citizen, Peter, and his wife from Sydney, said they enjoyed the IndoFest event. According to him, they gained a lot of new knowledge about Indonesian arts and crafts, especially after seeing the Indonesian Cultural Exhibition in Bali Kartini. The Indonesian Cultural Exhibition which held at the Kartini Hall in the Indonesian Embassy in Canberra. They presented various collections of fabrics, arts, and traditional musical instruments, distinctive houses to clothing, among others from the provinces of Lampung, Kalimantan, Sulawesi, Java, East Nusa Tenggara, Papua, Bali, and Maluku. Confiscate visitor's attention. The series of events during IndoFest consisted of a food and beverage bazaar, music and dance, an Indonesian cultural exhibition, and a kid's corner with a variety of traditional Indonesian children's toys that introduced to Australian children. (CultureKemdikbud.go.id, 2016).

Australia is one of the leading markets contributing tourists to Indonesia. In 2014, Australia was ranked the third-largest contributor to tourists to Indonesia, with 1.1 million foreign tourists (VenueMagz.com 2015). Australia only lost to Singapore and Malaysia are ranked first and second. Therefore, to boost the visit of Australian tourists to Indonesia, mainly so that not only to Bali, the Australia Indonesia Association in South Australia held IndoFest on 5-6 October 2015. The Indonesian Ministry of Tourism supports the event which has entered its eighth year. Also, Flinders University (presenting partner) and the Adelaide City Council as sponsors of this activity supported by the Honorary Consulate of the Republic of Indonesia in 
Adelaide and the Indonesian Embassy in Canberra. Various communities in South Australia collaborate with the primary goal of introducing Indonesia to the people of South Australia through arts, culture, music, food, and Indonesian. Besides, there is also a mission to increase interest and study of Indonesian culture and language, as well as a forum to provide opportunities to expand networks for sponsors, South Australian Government officials, and Indonesia. The Ministry of Tourism also opened exhibition stalls to intensify the Wonderful Indonesia program. This stand also provides information about Indonesian tourism, especially relating to further information about tourist destinations in Indonesia. Here, many visitors ask what the tourist destinations in Indonesia besides Bali are. Not only tourist destinations, but many visitors also invaded information about culinary in Indonesia after the IndoFest activities in Canberra were held. Visitors, especially Australians, asked where they could find Indonesian cuisine.

Specifically, for the Indonesian Embassy in Canberra, Indonesia has three Indonesian food stalls. The IndoFest event expected to be able to increase tourist arrivals from Australia, given that 60 percent of Australian tourists are repeat tourists, which means they have traveled to Indonesia more than once (VenueMagz.com 2015). Therefore it can be concluded that the first visit to Indonesia gave a good impression there is a desire to come back. Based on data from the Ministry of Tourism, for statistics on the number of tourists Australians who entered Indonesia in the period of 2012 to 2016 showed a significant increase. In 2012, there were 909 176 thousand Australians who came to Indonesia. Also, In 2013, there were 938,379 thousand Australians who came to Indonesia. For 2014 there were 1,098,383 million Australians who came to Indonesia. In 2015 there were 1,051,141 million Australians who came to Indonesia. And for 2016, 1,198,033 million Australians are coming to Indonesia. To further clarify the number of increases in Australians entering Indonesia, the following data provided with a visit Australian tourists to Indonesia.

Table 1. Data on Australian Tourist Visits to Indonesia

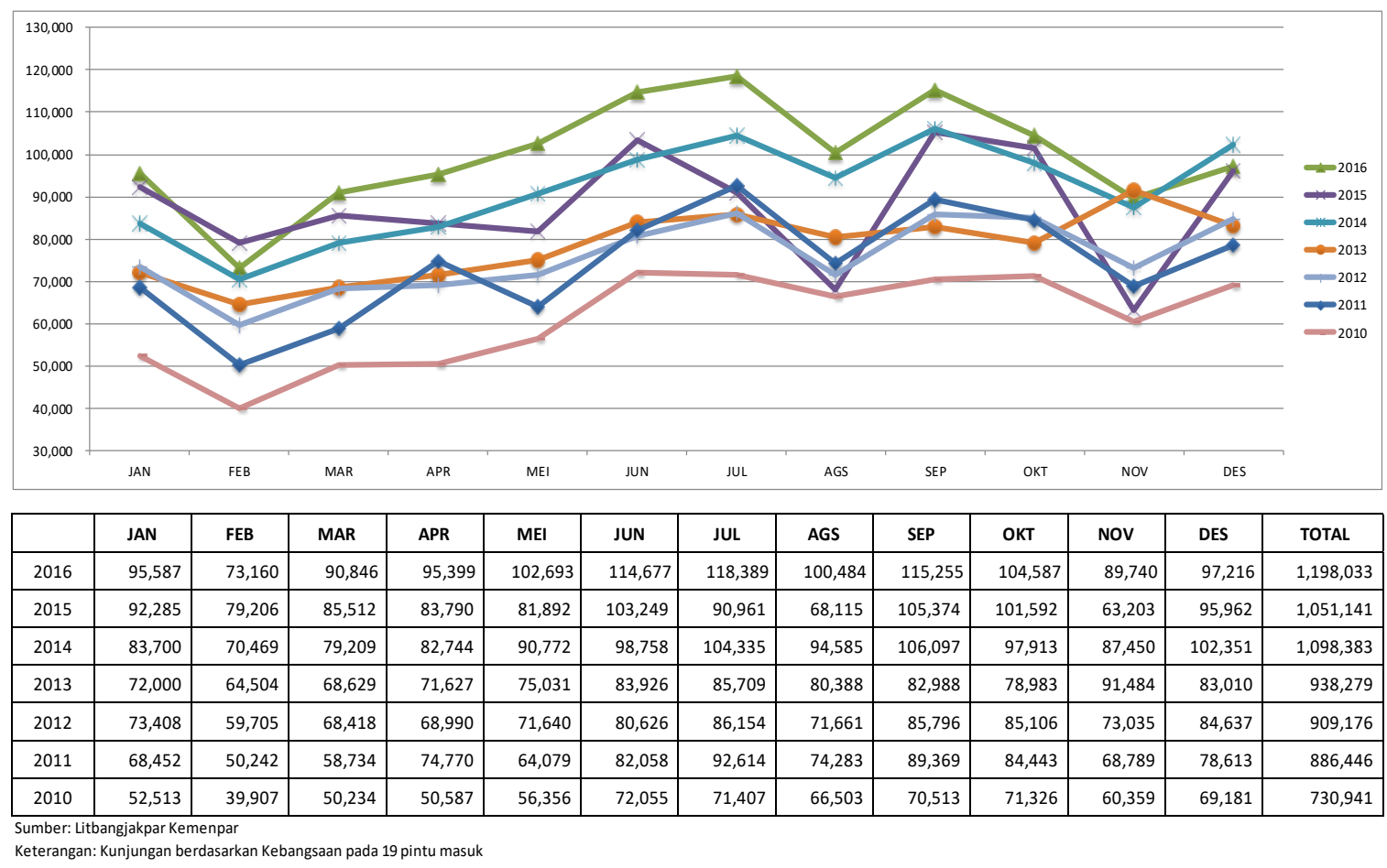


As a comparison, based on data obtained from the Indonesian Embassy in Canberra related to the interest of Australian tourists to Indonesia, in 2014, there were one million eight 1,080,000 people who visited Indonesia. In 2015 there was one point two million 1,200,000 who visited Indonesia, and in 2016 there were one million two hundred forty-eight 1,248,000 who came to Indonesia (Indonesian Embassy in Canberra 2016). Through the data on the number of Australian tourists visiting Indonesia, it is also evidence that IndoFest conducted to attract foreign tourists to enter Indonesia through the introduction of culture in the form of music or songs, culinary cuisine. Indonesia, as well as typical Indonesian dances, were successfully performed by Indonesia. With the success of the cultural diplomacy undertaken by the Government of Indonesia towards Australia through IndoFest, especially for the 20122016 period, the theories mentioned earlier show that diplomacy has a vital role to play. Play in international relations. One of the parts of diplomacy itself is to maintain good relationships in the global world. Through IndoFest's activities, Indonesia introduced more closely the various arts, culture, and special foods of Indonesia to the people of Australia who ultimately wanted to visit Indonesia directly. Public diplomacy is part of the implementation of soft power. Through public diplomacy, which aims to provide an understanding of one of the cultural values that are owned by a country, Indonesia formed IndoFest to introduce things or uniqueness and advantages that are owned by Indonesia that is not necessarily held by another country. It's one of the objectives of the Government of Indonesia to introduce Indonesian culture to the world consistently. With the IndoFest activities, especially those in Adelaide and Canberra, the Australian community can visit these activities and experience and spread the knowledge gained through various activities and stands or outlets available duringIndoFest.

With Indonesia's culture as a national identity, the Government conducts cultural diplomacy in its relations with Australia. Through IndoFest, live bands and art performances are presented from Aceh to Papua. Starting from angklung, Ega Robot Ethnic Percussion West Java, Banyuwangi Jejer Dance, Lombok traditional warfare presented through Peresean Dance, Bali Kecak Dance, Papua Pangkur Sago Dance to carnival costume that was exhibited by Malang Amore Carnival. From several art performances in IndoFest, uniquely Balinese Gamelan, Saman Dance, and Manuk Dadali, most played by Australians, including students. The series of events for IndoFest consists of a food and beverage bazaar, music and dance, an Indonesian cultural exhibition, and a kid's corner with a variety of traditional Indonesian children's toys that introduced to Australian children. Through the preceding, it looked that the Government has succeeded in playing its role in cultural diplomacy, which realized in its relations with Australia through IndoFest.

As part of cultural diplomacy activities, IndoFest provides excellent opportunities for the implementation of cultural diplomacy practices by the Government of Indonesia. But the opposite also presents several challenges that must be observed by the Government of Indonesia. Cultural Diplomacy is one form of implementation of foreign policy that focuses more on the soft-power approach through various types of cultural activities, one of them, as shown by Indonesia through IndoFest activities in Australia. Of course, cultural diplomacy is not only carried out by Indonesia in Australia but also by various countries in the world. For example, sending arts and educational missions or exchanging crafts and cultural activities between the two countries. Indonesia, which blessed with diverse cultural wealth, has enormous opportunities in carrying out cultural diplomacy to various countries. Art or Indonesian culture can be a tool or a means of strengthening or enhancing bilateral relations between Indonesia and other countries. With such a varied lifestyle, it said that the propagation of Indonesian culture would not run out of ammunition or fuel to support the implementation of Indonesia's foreign policy in achieving its goals.

On the other hand, it cannot deny that the implementation of a country's diplomacy always has its challenges, some are smooth and successfully achieve their targets, but some 
diplomacies face obstacles so that they are not as smooth as expected. The same is true of cultural diplomacy, although so far, there have rarely been any failures in cultural diplomacy. Cultural Diplomacy aims to make the target country understand the culture of other countries so hoped that through cultural understanding or "cultural understanding" it can ultimately achieve a deeper understanding of "mutual understanding" of various issues that arise between the two countries. A concrete example of the challenges of cultural diplomacy experienced by Indonesia is the lack of understanding of African society towards Indonesia. African people tend to equate Indonesia with China because it comes from the Asian region. But the Government of Indonesia does not remain silent, the Indonesian Embassy in Windhoek in Namibia (Africa) every year participates in the Namibia Travel Fair in the country to introduce not only tourism objects but also cultural and culinary aspects of Indonesia. Although on a smaller scale than IndoFest, it turns out that the effort has succeeded in changing the Namibian community's view of Indonesia.

\section{Conclusions and Recommendations}

Australia is a partner and the closest neighboring country of Indonesia, where the two countries have established good relations for a long time. It looked when Indonesia had been a significant tourist destination for Australians since the early 1970s. For this reason, Indonesia has taken various measures to attract Australian tourists. One of the efforts made by Indonesia is to carry out IndoFests activities as a cultural performance intended to introduce and add broader insights regarding Indonesian culture.

As one of the leading markets contributing tourists to Indonesia, in 2014, Australia was ranked the third-largest contributor to tourists, with 1.1 million foreign tourists. IndoFest, besides being an event to strengthen unity and the unity of Indonesian people living in Australia, so that the Indonesian people will be more proud of their cultural and culinary riches.

The IndoFest event has proven to be able to increase tourist arrivals from Australia, given that 60 percent of Australian tourists are repeaters. Through this, it looked that the first visit to Indonesia gives a good impression so that there is a desire of foreign citizens to come back.

For the future progress of the implementation of IndoFest, I Hope that the Government of Indonesia will involve more Indonesian organizations or communities. Such as the Indigenous Peoples' Alliance of the Archipelago (AMAN), the Alliance of Indigenous Peoples of Central Sulawesi (AMASUTA) or other cities related to dance and music traditional, representing various provinces in Indonesia to create more creative activities, such as Indonesian cuisine cooking competitions by Australians assisted by Indonesian people living in Australia, or training in traditional Indonesian dances representing each province in Indonesia. There are many activities, such as film screenings, also workshops and fashion shows, such as film screenings about Indonesia. Then there is a fashion show for traditional clothing representing all provinces in Indonesia, as well as workshops such as angklung, gamelan, or kulintang. Archipelago fabric workshops, such as Sasirangan from South Kalimantan, Ulos from Batak, Sarong Bugis from Makassar, etc. so they routinely featured in IF so people in Australia are more familiar with each region in Indonesia and its uniqueness.

To strengthen Indonesia's Cultural Diplomacy, the Government needs to hold IndoFest activities that are not only carried out in Australia but also in other countries. It intended to maximize the introduction of Indonesian culture; for that, the development of IndoFest increasingly requires the participation of Indonesian people.

There is a need for a complete outreach of IndoFest activities, including details of the performances presented during IndoFest, to provide a further picture of the promotion of Indonesian culture internationally. Also, additional writing is needed to highlight the IndoFest 
course of activities relating to the benefits and effectiveness of these cultural activities as part of the public accountability and participation process. 


\section{BIBLIOGRAPHY}

\section{Books}

Adi, Rianto. 2004. "Metodologi Penulisan Sosial dan Hukum." 72. Jakarta: Granit.

Barston, R P. 1997. In Modern Diplomacy, 2nd Edition, 106. London and New York: Longman.

Berridge, G R, and Alan James. 2001. A Dictionary of Diplomacy. Basingstoke, Hampshire: Palgrave.

King, Anthony D. 1991. Culture Globalization and The World-System. London: Macmillan Press.

Melissen, Jan. 2005. "The New Public Diplomacy, Soft Power in International Relations." 12. New York: Palagrave Macmillan.

Mulyana, Deddy, and Solatun. 2013. Metode Penulisan Komunikasi (COntoh-contoh Penulisan Kualitatif dengan Pendekatan Praktis). bandung: Remaja Rosdakarya.

Nasir, Moch. 1999. Motodelogi Penulisan. Jakarta: Ghalia.

Nasir, Moh. 1999. Metode Penulisan. Jakarta: Ghalia Indonesia.

Nasution, S. 2012. Metode Research, Penulisan Ilmiah): Thesis, Disain Penulisan, Hipotesis, Validitas, Sampling, Populasi, Observasi, Wawancara, Angket. Jakarta: Bumi AKsara.

Nawawi, H Hadari, and H M. Hartini Hadari. 2006. Instrumen Penulisan Bidang Sosial. Yogyakarta: Gajah Mada Universty Press.

Prof.Sugiyono. 2009. Metode Penulisan Kuantitatif Kualitatif dan R \& D. Bandung: Alfabeta. Rana, Kishan S. 2011. In 21st Century Diplomacy A Practitioner's Guide, 79. India: continuum. Roy, S. L. 1991. In Diplomasi, 23. Jakarta: Rajawali Pers.

Ruslan, Rosady. 2003. In Metode Penulisan Public Relations dan Komunikasi, 31. Jakarta: Raja Grafindo Persada.

Silalahi, Ulber. 2009. In Metode Penulisan Sosial, 284-285. Bandung: Refika Aditama.

Soesastro, Hadi. 1995. In Indonesia-Australia Relations: Diverse Cultures, Converging Interests., 5. Jakarta: , Cente for Strategic and Intermational Studies.

Tim Penulis Universitas Udayana Denpasar-Bali. 1989. Langkah untuk Mensukseskan Festival Kebudayaan Indonesia 1990-1991. Denpasar: Universitas Udayana.

\section{Journals}

Badan Penulisan dan Pengembangan Departemen Luar Negeri. 1987. Pariwisata Sebagai Pendukung dalam Rangka Pelaksanaan Diplomasi di Bidang Kebudayaan (Kajian Pustaka). Jakarta: Badan Penulisan dan Pengembangan Departemen Luar Ngereri.

Bhakti, Ikrar Nusa. 2008. "Hubungan Indonesia-Australia Pasca Kemenangan Partai Buruh." Jurnal Luar Negeri, Menjalin Keakraban Baru Indonesia- Australia (Badan Pengkajian dan Pengembangan Kebijakan Departemen Luar Negeri RI) 25 (1): 33. Hlm 32-42

Ikrar Nusa Bhakti. 2008. "Indonesia-Australia: Tantangan dan Peluang,." Jurnal Luar Negeri Menjalin Keakraban Baru Indonesia-Australia 28: 27.

Jora, Lucian. 2013. "New Practices and Trends." Future Trends on Cultural Diplomacy (Institute of Political Sciences and International Relations, Romanian Academy) 48:4452.

Media, Biro Administrasi Menteri Direktorat Informasi dan. 2014. Diplomasi Indonesia 2013. Jakarta: Direktorat Informasi dan Media, Direktorat Jenderal Informasi dan Diplomasi Publik, Kementerian Luar Negeri RI. 
Molaei, Hamideh. 2014. "Social Media Usage, Social Relations, and a Sense of Community in Indonesia." International Journal of Interactive Communication Systems and Technologies 4 (2): 52.

Panggabean, Freddy M. 2009. "Cultural Diplomacy as Indonesia's Soft Power: the need for a Cultural Institute." Jurnal Diplomasi (Kementerian Republik RI) 5 (2): 1.

Panggabean, Freddy M. 2013. "Cultural Diplomacy as Indonesia's Soft Power: the Need for a Cultural Institute." Jurnal Diplomasi. Budaya dalam Soft Diplomacy Indonesia (Kementerian Luar Negeri RI) 5 (2): 5.

Prabaningtyas, Rizka F. 2013. "Indonesia-Australia: Menguji Persahabatan di Tengah Konflik Penyadapan." Institute of International Studies 20 (2):1- 2.

\section{Internet}

Adelaide.edu.au.2014. April 9. Accessed April 2017. https://blogs.adelaide.edu.au/isc/2014/04/09/IndoFest-2014/.

Australiaplus.com. Accessed April 11, 2017. http://www.australiaplus.com/indonesian/wisatanad-budaya/festival-indonesia-2016/7980282.

Communityswitch.com.au. 2014. Oktober. Accessed Mei 29, 2017.

Cnnindonesia.com.2016. September 27. Accessed April 10, 2017. http://www.cnnindonesia.com/gaya-hidup/20160927141535-307-161451/IndoFest2016-sukses-tampilkan-budaya-indonesia-di-adelaide/.

IndoFest.com.au.2016. September 21. Accessed Oktober 31, 2016. IndoFest.com.au/about-IndoFest-adelaide/.

IndoFest.com.au. Accessed Mei 20, 2017. http://IndoFest.com.au/about-aiasa-australianindonesian-association-of-south-australia-inc/.

Internasional.kompas.com.2008. Accessed April 20, 2017.

internasional.kompas.com/read/2008/04/14/02533776/festival.indonesia.digelar.pertama.di.a ustralia.selatan.

Kebudayaan.kemdikbud.go.id.2015. Oktober 11. Accessed Oktober 30, 2016. http://kebudayaan.kemdikbud.go.id/ditwdb/2015/10/14/festival-indonesia-jadi-ikonbudaya-ibu-kota-australia/.

Kebudayaan.kemdikbud.go.id.2016. Accessed April 2017. http://kebudayaan.kemdikbud.go.id/ditwdb/2015/10/14/festival-indonesia-diaustralia/.

M.metrotvnews.com.2015. Oktober 6. Accessed April 15, 2017. http://m.metrotvnews.com/abc/read/2015/10/06/1500382.

Nasional.kompas.com.2008. April 14. Accessed Maret 16, 2017. http://nasional.kompas.com/read/2008/04/14/02533776/festival.indonesia.digelar.pert ama.di.australia.selatan.

Nasional.kompas.com.2016. $\quad$ Accessed $\quad$ April 2017. http://nasional.kompas.com/read/2016/09/29/051100527/IndoFest.2016.festival.palin g.akbar.di.australia.selatan.

News.detik.com. 2015. Accessed Mei 15, 2017. http://news.detik.com /australiaplus/3037236/IndoFest-2015-perekat-hubungan-indonesia-australia.

Venuemagz.com.2015. Oktober 12. Accessed April 24, 2017. http://venuemagz.com/event/IndoFest-ajang-memikat-wisatawan-australia/.

Radioaustralia.net.au.2015. Accessed $\quad$ April 2017. http://www.radioaustralia.net.au/indonesian/2015-10-06/IndoFest-2015-perekathubungan-indonesiaaustralia/1500382. 
